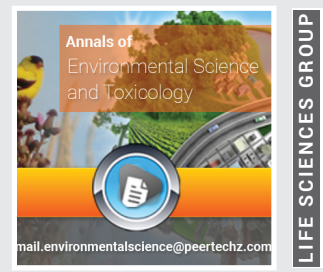

\title{
(3). Annals of
}

\section{Vijay K Bharti*, Arup Giri and Krishna Kumar}

Defence Institute of High Altitude Research (DIHAR), DRDO, Leh-Ladakh, Jammu \& Kashmir, India

Dates: Received: 30 December, 2016; Accepted: 12 January, 2017; Published: 18 January, 2017

*Corresponding author: Vijay K Bharti, Defence Institute of High Altitude Research (DIHAR), DRDO, Leh-Ladakh, Jammu \& Kashmir, India, E-mail: vijaykbharti@rediffmail.com

Keywords: High altitude; Minerals; Physico-chemical; Water quality

https://www.peertechz.com
Research Article

Evaluation of Physico-Chemical Parameters and Minerals Status of Different Water Sources at High Altitude

\begin{abstract}
Physico-chemical properties and minerals status is an important decisive factor for assessment of drinking water quality. There are limited literatures on this aspect for drinking water quality of high altitude areas; therefore, the present investigation was carried out to evaluate different physico-chemical parameters and some essential minerals status in different drinking water sources. These water samples were collected from different sources like deep tube well, spring, and river from different villages of Leh District, Jammu \& Kashmir, India. Thereafter, it was analyzed for physico-chemical parameters viz. dissolve oxygen, alkalinity, hardness, chloride, phosphate, sulphate, and nitrate according to standard methods. Similarly, all the essential minerals viz. sodium, calcium, magnesium, potassium, iron, sulphur, and manganese were analyzed by using Inductively Coupled Plasma Optical Emission Spectroscopy (ICP-OES). All the results were compared with the WHO standard for drinking water. The findings of this investigation indicated that dissolved oxygen, alkalinity and hardness were above the desirable level at some places as per WHO standards. Whereas, chloride, nitrate, and sulphate levels were lower in all the water samples collected across the sources. Among all the minerals, iron, potassium and aluminium level were above and sodium, magnesium, and manganese were lower than the desirable level at all the different altitude as per WHO standards. Interestingly, chloride, sodium, sulphur and aluminium level were high in Indus river water collected from the nearby city area. Therefore, it can be concluded that water sources near the city area are more contaminated than the other sites. Hence, present findings indicated variation in physico-chemical parameters and mineral status of water of different sources of high altitude Himalayan region. More or less, the quality of drinking water is suitable for consumption except the hardness and aluminium level.
\end{abstract}

\section{Introduction}

Water is an essential component of our food and contributes to many minerals nutrients, too [1,2]. Important natural sources of water are surface water such as lakes, streams, river, pond, etc. and ground water such as bore well and wells [3]. Fresh water is essential for agriculture, industry, domestic use, and drinking purpose for human and animals [4]. Water quality depends upon the physical, chemical, minerals, and biological characteristics of water [6]. Hence, animal and human health as well as sustainable agricultural and industrial development will not be possible without availability of quality fresh water in adequate quantity [6]. In general, water sources are less anthropogenic contaminated in Himalayan region as compared to plain areas due to less industrial growth and low human population with comparison to plain areas. However, in recent years due to increase in human population, tourism, and industrialization, water sources are brink of contamination on indiscriminate waste disposal. Leaching of this water into ground water at different strata of rock further contribute to ground water contamination [7-9]. Recently, due to environmental pollution, several surface water sources are not acceptable for drinking as these are often contaminated with various organic, inorganic, and microbial agents $[6,7,10-$ 15]. According to $\mathrm{WHO}$, about $80 \%$ of all the diseases in human beings are caused by water? It is therefore becomes imperative to regularly monitor the quality of water and to device ways and means to protect it [16]. Some reports on soil, water and fodder minerals status indicated deficiency or excess of some minerals at high altitude $[17,18]$. Since, physico-chemical properties and mineral status are interlinked with mineral availability of water. The composition of surface and groundwater vary with the altitude, topography, hydrological and biological present in the drainage basin $[19,20]$. Therefore, evaluation 
of different sources of water collected from different altitude is essential for knowing their suitability for drinking purpose. Since, the scanty of literatures on water quality of high altitude collected from different sources; therefore it is important to evaluate physico-chemical properties and minerals status. Therefore, we investigated physico-chemical parameters and some minerals in all the water collected from different sources at high altitude. This study will help in identification of good water sources and developing remedial measures for water resource management at high altitude.

\section{Materials and Methods}

\section{Study area}

The study area occupies a part of the Indus river valley. The Indus River in the study area flows throughout the year. The overall drainage system is controlled by the river and many canals which are filled through glacier melted water. In the summer season, irrigation is fully dependent on these canal systems. The characteristics of rocks in this region are igneous, metamorphic and sedimentary in nature. They have Tertiary granitic batholith of Ladakh. The area remained magmatically active from Cretaceous to post-Oligocene period. They are shale and limestone. Leh plains are underlain by moraine deposits consisting of boulders, cobbles, pebbles embedded in an arenaceous matrix and lake deposits comprising predominantly of clays, sandy clays and silt. Ground water development through construction of tube wells and hand pumps is very much possible in this district. Till date ground water development in this district was in ancient stage. People mainly depend on surface water sources and springs for meeting water supply requirements. Thus, the stage of ground water development is least [21].

In this study, tube well water (26 total sites), spring water (02 total sites) and river water (05 total sites) were collected from different sites/places at different altitude of Leh district, Jammu \& Kashmir, India in the winter season of 2013. Collection sites are located in the cold, arid Himalayan region of India, where the altitude varies between 10465-11884 ft above mean sea level (MSL). Different altitude, latitude and longitude of all the sampling sites/places were recorded by GPS system (Model no. Garmin GPS $72 \mathrm{H}$ ) and distance of sites/places from main city/industry were given in Table 1 followed by the sampling location map made by the Google Earth 6.1 and QGIS 2.12 software (Figure 1).

\section{Preparation of water samples}

The water samples were collected from different sites in plastic bottles, which were previously washed with detergents and $\mathrm{HNO}_{3}$ acid and later rinsed with sampled water several times. Total $1.5 \mathrm{~mL}$ of $2 \mathrm{M} \mathrm{HNO}_{3}$ was added to each $100 \mathrm{~mL}$ samples $(\mathrm{pH}<3)$ for metallic ions determination to maintain the stability of the oxidation state of the various elements in solution and prevent precipitation [22].

\section{Analysis of physico-chemical and minerals parameters}

All the water samples were analyzed for dissolve oxygen, alkalinity, hardness, chloride, phosphate, sulphate, nitrate, sodium, calcium, magnesium, potassium, iron, sulphur, manganese and aluminium of tube well, spring water and river water as per standard procedures used for water analysis. All the analytical methods are briefly described below and given in Table 2.

DO was determined by Winkler method [23]. Alkalinity was estimated by titrimetric method [24]. Total Hardness and calcium hardness was determined by complex metric titration using Eriochrome Black-T as an indicator by EDTA method and Chloride was estimated by Mohr's method using $\mathrm{AgNO}_{3}$ solution and Potassium Chromate as an indicator [24]. Sulphates and Nitrates were estimated by UV-Visible Spectrophotometer (Biosync Tecknology Pvt Ltd, Model no.LT2900) [25], inorganic phosphates were determined by UVVisible Spectrophotometric method [24]. All the minerals viz.

Table 1: Details of sampling site and sources of water.

\begin{tabular}{|c|c|c|c|c|c|}
\hline \multirow[b]{2}{*}{$\begin{array}{l}\text { Sampling Site } \\
\text { Nomenclature }\end{array}$} & \multirow[b]{2}{*}{$\begin{array}{c}\text { Water } \\
\text { sources }\end{array}$} & \multicolumn{4}{|c|}{ Details of sampling sites } \\
\hline & & \begin{tabular}{|} 
Approximate \\
distance \\
from main \\
city
\end{tabular} & Latitude & Longitude & $\begin{array}{c}\text { Altitude } \\
\text { (ft) }\end{array}$ \\
\hline S1 & Indus River & $35 \mathrm{~km}$ & $34^{\circ} 02^{\prime} 26.32^{\prime \prime} \mathrm{N}$ & $77^{\circ} 39^{\prime} 54.59^{\prime \prime} \mathrm{E}$ & 10688 \\
\hline S2 & Indus River & $35 \mathrm{~km}$ & $34^{\circ} 02^{\prime} 23.79^{\prime \prime} \mathrm{N}$ & $77^{\circ} 39^{\prime} 57.63^{\prime \prime} \mathrm{E}$ & 10587 \\
\hline S3 & Indus River & $35 \mathrm{~km}$ & $34^{\circ} 02^{\prime} 21.31^{\prime \prime N}$ & $77^{\circ} 39^{\prime} 59.29^{\prime \prime} \mathrm{E}$ & 10696 \\
\hline S4 & Tube well & $5 \mathrm{~km}$ & $34^{\circ} 06^{\prime} 40.04^{\prime \prime} \mathrm{N}$ & $77^{\circ} 35^{\prime} 19.20^{\prime \prime} \mathrm{E}$ & 10620 \\
\hline S5 & Tube well & $5 \mathrm{~km}$ & $34^{\circ} 06^{\prime} 25.55^{\prime \prime} \mathrm{N}$ & $77^{\circ} 35^{\prime} 05.00^{\prime \prime} \mathrm{E}$ & 10550 \\
\hline S6 & Tube well & $5 \mathrm{~km}$ & $34^{\circ} 06^{\prime} 29.49^{\prime \prime} \mathrm{N}$ & $77^{\circ} 34^{\prime} 51.06^{\prime \prime} \mathrm{E}$ & 10557 \\
\hline S7 & Tube well & $5 \mathrm{~km}$ & $34^{\circ} 04^{\prime} 01.87^{\prime \prime} \mathrm{N}$ & $77^{\circ} 37^{\prime} 47.35^{\prime \prime} \mathrm{E}$ & 10624 \\
\hline S8 & Tube well & $5 \mathrm{~km}$ & $34^{\circ} 04^{\prime} 18.10^{\prime \prime} \mathrm{N}$ & $77^{\circ} 38^{\prime} 13.89^{\prime \prime} \mathrm{E}$ & 10665 \\
\hline s9 & Tube well & $10 \mathrm{~km}$ & $34^{\circ} 07^{\prime} 28.49^{\prime \prime} \mathrm{N}$ & $77^{\circ} 31^{\prime} 19.57^{\prime \prime} \mathrm{E}$ & 10476 \\
\hline $\mathrm{S} 10$ & Tube well & $10 \mathrm{~km}$ & $34^{\circ} 07^{\prime} 39.60^{\prime \prime} \mathrm{N}$ & $77^{\circ} 31^{\prime} 18.75^{\prime \prime} \mathrm{E}$ & 10482 \\
\hline S11 & Tube well & $10 \mathrm{~km}$ & $34^{\circ} 07^{\prime} 30.19^{\prime \prime} \mathrm{N}$ & $77^{\circ} 31^{\prime} 17.42^{\prime \prime} \mathrm{E}$ & 10472 \\
\hline $\mathrm{S} 12$ & Tube well & $10 \mathrm{~km}$ & $34^{\circ} 07^{\prime} 29.72^{\prime \prime} \mathrm{N}$ & $77^{\circ} 30^{\prime} 59.18^{\prime \prime} \mathrm{E}$ & 10465 \\
\hline $\mathrm{S} 13$ & Tube well & $10 \mathrm{~km}$ & $34^{\circ} 07^{\prime} 26.48^{\prime \prime} \mathrm{N}$ & $77^{\circ} 31^{\prime} 02.73^{\prime \prime} \mathrm{E}$ & 10465 \\
\hline S14 & Tube well & $35 \mathrm{~km}$ & $34^{\circ} 02^{\prime} 15.47^{\prime \prime} \mathrm{N}$ & $77^{\circ} 40^{\prime} 13.74^{\prime \prime} \mathrm{E}$ & 10704 \\
\hline S15 & Tube well & $7 \mathrm{~km}$ & $34^{\circ} 07^{\prime} 46.27^{\prime \prime} \mathrm{N}$ & $77^{\circ} 31^{\prime} 33.40^{\prime \prime} \mathrm{E}$ & 10547 \\
\hline S16 & Tube well & $10 \mathrm{~km}$ & $34^{\circ} 03^{\prime} 54.81^{\prime \prime} \mathrm{N}$ & $77^{\circ} 38^{\prime} 13.56^{\prime \prime} \mathrm{E}$ & 10627 \\
\hline S17 & Tube well & $10 \mathrm{~km}$ & $34^{\circ} 03^{\prime} 54.55^{\prime \prime} \mathrm{N}$ & $77^{\circ} 38^{\prime} 26.51^{\prime \prime} \mathrm{E}$ & 10627 \\
\hline S18 & Tube well & $35 \mathrm{~km}$ & $34^{\circ} 02^{\prime} 08.31^{\prime \prime} \mathrm{N}$ & $77^{\circ} 40^{\prime} 29.66^{\prime \prime} \mathrm{E}$ & 10712 \\
\hline S19 & Tube well & $10 \mathrm{~km}$ & $34^{\circ} 03^{\prime} 56.66^{\prime \prime} \mathrm{N}$ & $77^{\circ} 38^{\prime} 37.24^{\prime \prime} \mathrm{E}$ & 10640 \\
\hline $\mathrm{S} 20$ & Tube well & $10 \mathrm{~km}$ & $34^{\circ} 04^{\prime} 03.99^{\prime \prime} \mathrm{N}$ & $77^{\circ} 38^{\prime} 45.74^{\prime \prime} \mathrm{E}$ & 10665 \\
\hline S21 & Tube well & $10 \mathrm{~km}$ & $34^{\circ} 03^{\prime} 59.31^{\prime \prime} \mathrm{N}$ & $77^{\circ} 38^{\prime} 57.69^{\prime \prime} \mathrm{E}$ & 10687 \\
\hline $\mathrm{S} 22$ & Tube well & $35 \mathrm{~km}$ & $34^{\circ} 02^{\prime} 11.32^{\prime \prime} \mathrm{N}$ & $77^{\circ} 40^{\prime} 17.32^{\prime \prime} \mathrm{E}$ & 10702 \\
\hline $\mathrm{S} 23$ & Indus River & $35 \mathrm{~km}$ & $34^{\circ} 02^{\prime} 16.12^{\prime \prime} \mathrm{N}$ & $77^{\circ} 39^{\prime} 58.29^{\prime \prime} \mathrm{E}$ & 10695 \\
\hline S24 & Indus River & $35 \mathrm{~km}$ & $34^{\circ} 02^{\prime} 19.44^{\prime \prime} \mathrm{N}$ & $77^{\circ} 40^{\prime} 00.01^{\prime \prime} \mathrm{E}$ & 10694 \\
\hline S25 & Spring & $25 \mathrm{~km}$ & $34^{\circ} 111^{\prime} 00.56^{\prime \prime} \mathrm{N}$ & $77^{\circ} 29^{\prime} 27.15^{\prime \prime} \mathrm{E}$ & 11884 \\
\hline S26 & Spring & $35 \mathrm{~km}$ & $34^{\circ} 03^{\prime} 36.57^{\prime \prime} \mathrm{N}$ & $77^{\circ} 33^{\prime} 12.95^{\prime \prime} \mathrm{E}$ & 11559 \\
\hline S27 & Tube well & $35 \mathrm{~km}$ & $34^{\circ} 02^{\prime} 07.50^{\prime \prime} \mathrm{N}$ & $77^{\circ} 40^{\prime} 20.66^{\prime \prime} \mathrm{E}$ & 10714 \\
\hline $\mathrm{S} 28$ & Tube well & $35 \mathrm{~km}$ & $34^{\circ} 02^{\prime} 04.18^{\prime \prime} \mathrm{N}$ & $77^{\circ} 40^{\prime} 22.45^{\prime \prime} \mathrm{E}$ & 10706 \\
\hline S29 & Tube well & $35 \mathrm{~km}$ & $34^{\circ} 02^{\prime} 05.18^{\prime \prime} \mathrm{N}$ & $77^{\circ} 40^{\prime} 28.18^{\prime \prime} \mathrm{E}$ & 10716 \\
\hline S30 & Tube well & $35 \mathrm{~km}$ & $34^{\circ} 02^{\prime} 07.36^{\prime \prime} \mathrm{N}$ & $77^{\circ} 40^{\prime} 27.28^{\prime \prime} \mathrm{E}$ & 10710 \\
\hline S31 & Tube well & $25 \mathrm{~km}$ & $34^{\circ} 02^{\prime} 27.34^{\prime \prime} \mathrm{N}$ & $77^{\circ} 38^{\prime} 47.94^{\prime \prime} \mathrm{E}$ & 10674 \\
\hline S32 & Tube well & $25 \mathrm{~km}$ & $34^{\circ} 02^{\prime} 13.01^{\prime \prime} \mathrm{N}$ & $77^{\circ} 39^{\prime} 04.90^{\prime \prime} \mathrm{E}$ & 10702 \\
\hline S33 & Tube well & $25 \mathrm{~km}$ & $34^{\circ} 02^{\prime} 40.43^{\prime \prime} \mathrm{N}$ & $77^{\circ} 39^{\prime} 14.76^{\prime \prime} \mathrm{E}$ & 10679 \\
\hline
\end{tabular}




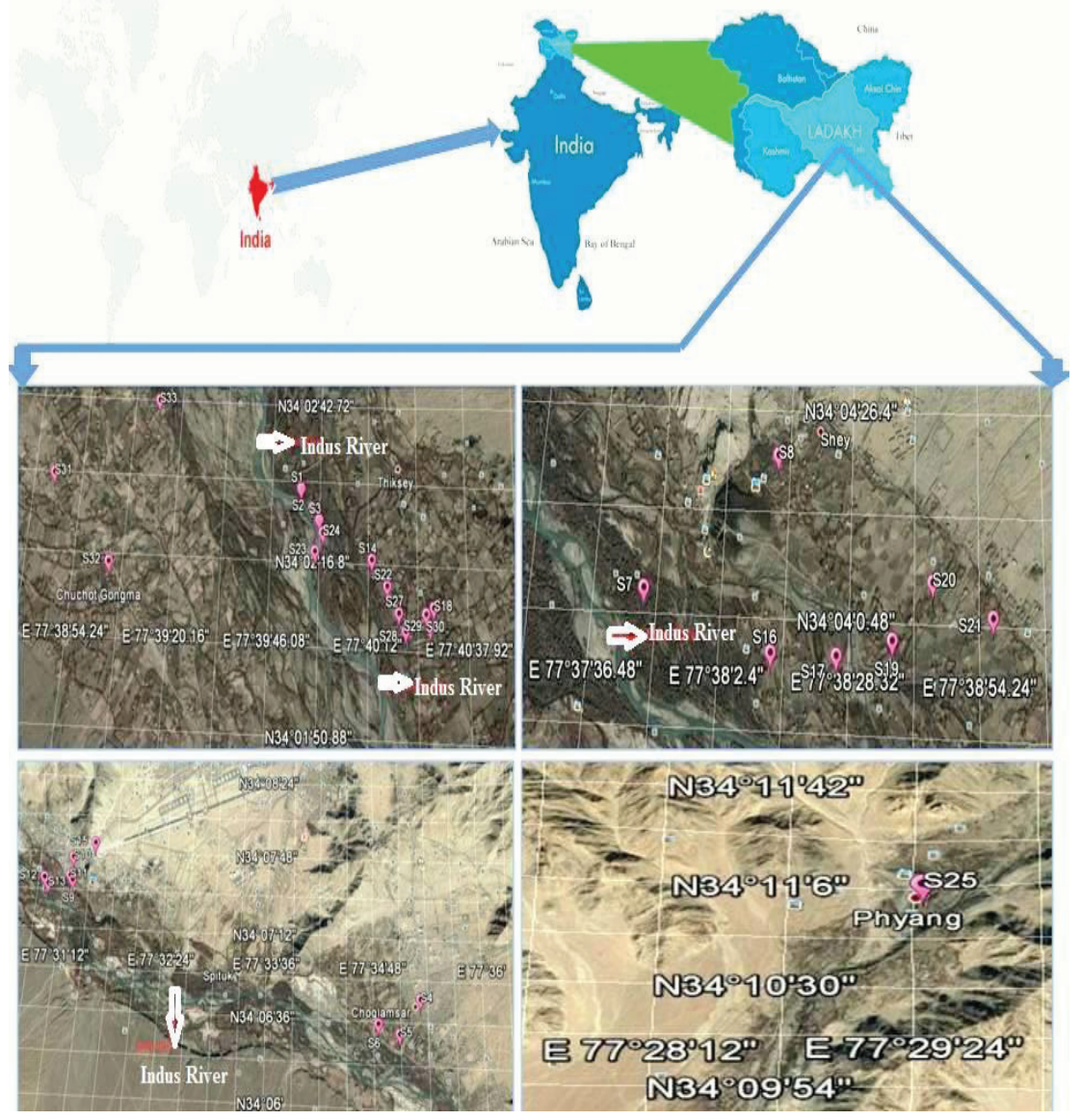

Figure 1: Location of drinking water sampling sites around Leh district. Map presented in the grid view with the help of Google Earth 6.1 and QGIS 2.12 software.

Table 2: Methods and equipments used for water quality analysis.

\begin{tabular}{|c|c|c|c|c|c|}
\hline SI. No. & Parameter & Unit & Method/Equipment used & Reference \\
\hline 1 & Total Hardness & $\mathrm{mg} / \mathrm{L}$ & EDTA Titrimetric Method & {$[24]$} \\
\hline 2 & Chloride & $\mathrm{mg} / \mathrm{L}$ & Mohr's Method & {$[24]$} \\
\hline 3 & Dissolve Oxygen & $\mathrm{mg} / \mathrm{L}$ & Winkler Method & {$[23]$} \\
\hline 4 & $\begin{array}{c}\text { Free Carbon } \\
\text { dioxide }\end{array}$ & $\mathrm{mg} / \mathrm{L}$ & Titrimetric method & {$[24]$} \\
\hline 5 & Alkalinity & $\mathrm{mg} / \mathrm{L}$ & Titrimetric method & {$[24]$} \\
\hline 6 & Sulphates & $\mathrm{mg} / \mathrm{L}$ & U.V. visible spectro-photometric & method & {$[25]$} \\
\hline 7 & Nitrate & $\mathrm{mg} / \mathrm{L}$ & U.V. visible spectro-photometry & {$[25]$} \\
\hline 8 & Phosphate & $\mathrm{mg} / \mathrm{L}$ & U.V. visible spectro-photometry & {$[24]$} \\
\hline 9 & Minerals & $\mathrm{mg} / \mathrm{L}$ & ICP-OES Instrumental method & - \\
\hline
\end{tabular}

Ca, Na, K, Mg, Mn, Fe, S and Al level were estimated by using Inductively Coupled Plasma Optical Emission Spectroscopy (ICP-OES) (Perkin-Elmer Analyst, Optima 7000 DV).

\section{Statistical analysis}

Six samples collected from each sites of different water sources were calculated by Microsoft excel worksheet and all the analyzed data were compared with recommended World Health Organization (WHO) standard values given in Table 3 [26].

\section{Results and Discussion}

The parameters like dissolve oxygen, alkalinity, hardness, chloride, sulphate, phosphate, and nitrate are important indices of quality water $[2,26,27]$. Dissolved oxygen (DO) is very important parameter in water assessment [28]. DO is governed by the water turbulence, surface diffusion, rate of photosynthesis, biological oxygen demand (BOD), water temperature, and carbon dioxide concentration [29,30]. In the present study, levels of DO in all the three sources are higher than the WHO prescribed guidelines (Figure 2). Level of dissolve oxygen in water depends upon the wind action and speed of water flow. As the river and spring water flowing, it has the open chances of water to mix up with natural oxygen. For these reason, river water and spring water might have higher dissolve oxygen level than the WHO prescribed limits. However, the quality of water is good for the aquatic habitat.

The Alkalinity of water is its capacity to neutralize a strong acid. It is normally due to the presence of carbonates, bicarbonates and hydroxides compounds of $\mathrm{Ca}^{2+}, \mathrm{Mg}^{2+}$ and $\mathrm{Na}^{+}$[31]. Water bodies having total alkalinity (Table 4, Figure 3) above $50 \mathrm{mg} / \mathrm{L}$ can be considered productive. Therefore, in the study area it might be said that water sources are highly productive [32]. However, in this region, soil showed the alkaline in nature $[17,18]$. This is the most probable reason for showing the higher level of alkalinity in all the three water sources than the WHO guidelines. 
Hardness is the property of water, which is due to the salts of $\mathrm{Ca}^{2+}$ and $\mathrm{Mg}^{2+}$ [31,33]. Level of hardness (Table 4, Figure 4) was higher in most sampling sites than the desirable limits prescribed by WHO guideline. Low magnesium level and high hardness value in the study sites indicates that hardness is mainly due to calcium level.

Chlorides usually occur as $\mathrm{NaCl}, \mathrm{CaCl}_{2}, \mathrm{MgCl}_{2}$, and in widely varying concentration in all natural water [34]. An increase in the number of chloride $\left(\mathrm{Cl}^{-}\right)$content of water may indicate possible pollution from human sewage, animal manure or industrial wastes [35]. In the present study, chloride concentration (Table 5, Figure 5) was below the permissible level of WHO guidelines. In the winter season, all the mentioned probable sources of chlorides to water remain low. For this reason, all the three water sources showed the lower level than the WHO guidelines.

\begin{tabular}{|c|c|c|}
\hline SI. No. & Parameters & WHO standard \\
\hline 1 & Temp $\left({ }^{\circ} \mathrm{C}\right)$ & NS\# \\
\hline 2 & $\mathrm{pH}$ & $6.5-8.5$ \\
\hline 3 & $\mathrm{DO}(\mathrm{mg} / \mathrm{L})$ & $4-6$ \\
\hline 4 & Free $\mathrm{CO}_{2}(\mathrm{mg} / \mathrm{L})$ & $N / A^{*}$ \\
\hline 5 & Total Hardness (mg/L) & 100 \\
\hline 6 & Total alkalinity $(\mathrm{mg} / \mathrm{L})$ & 250 \\
\hline 7 & Chlorides (mg/L) & 250 \\
\hline 8 & Phosphate (mg/L) & $N / A^{*}$ \\
\hline 9 & Sulphates (mg/L) & 500 \\
\hline 10 & Nitrate $(\mathrm{mg} / \mathrm{L})$ & 50 \\
\hline 11 & Iron (mg/L) & 0.3 \\
\hline 12 & Calcium (mg/L) & 100 \\
\hline 13 & Magnesium (mg/L) & 20 \\
\hline 14 & Sodium (mg/L) & 200 \\
\hline 15 & Manganese (mg/L) & 0.4 \\
\hline 16 & Aluminium (mg/L) & 0.3 \\
\hline 17 & Sulphur (mg/L) & $N / A^{*}$ \\
\hline 18 & Potassium (mg/L) & 12 \\
\hline
\end{tabular}

\#NS: Non significant, *N/A: Not Available.

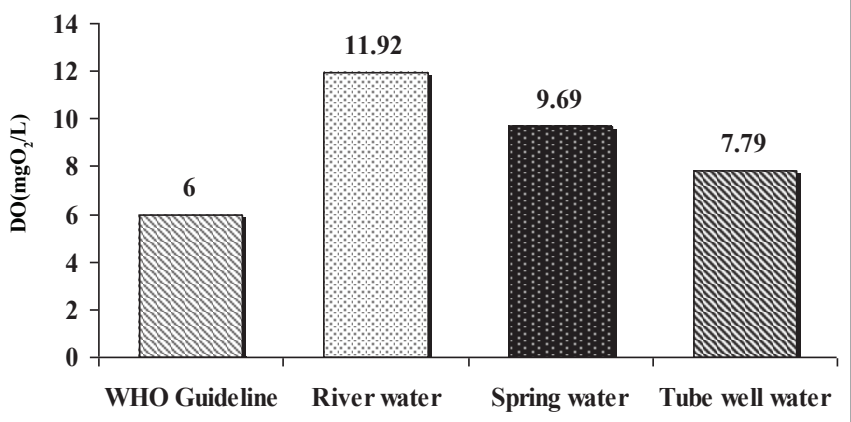

Figure 2: Mean dissolve oxygen (DO) concentration of three water sources compared with drinking water quality standard of WHO.
Table 4: Physico-chemical quality of water collected from different sites at high altitude.

\begin{tabular}{|c|c|c|c|c|c|}
\hline Sites no. & Water sources & $\begin{array}{c}\text { DO } \\
(\mathrm{mg} / \mathrm{L})\end{array}$ & $\begin{array}{c}\text { Free } \mathrm{CO}_{2} \\
(\mathrm{mg} / \mathrm{L})\end{array}$ & $\begin{array}{c}\text { Alkalinity } \\
\text { (mg/L) }\end{array}$ & $\begin{array}{c}\text { Hardness } \\
(\mathrm{mg} / \mathrm{L})\end{array}$ \\
\hline 1 & \multirow{3}{*}{ Indus River } & $14.20^{\star \star}$ & 13.30 & $269.00 * \star$ & 192.00 ** \\
\hline 2 & & $12.80 * \star$ & 14.70 & $263.50^{\star \star}$ & $150.00^{\star \star}$ \\
\hline 3 & & $12.20^{* *}$ & 14.90 & $267.00^{\star \star *}$ & $150.00^{\star \star}$ \\
\hline 4 & \multirow{19}{*}{ Tube well } & $8.40^{\star \star}$ & 14.66 & $263.15^{\star \star}$ & $200.00^{* *}$ \\
\hline 5 & & $8.00^{* \star}$ & 15.00 & $260.00^{\star \star *}$ & $232.00^{\star \star}$ \\
\hline 6 & & $9.10^{\star *}$ & 14.00 & 266.00 ** & $254.00^{* *}$ \\
\hline 7 & & $8.20^{\star \star}$ & 17.20 & $267.00^{\star \star}$ & $249.00^{* *}$ \\
\hline 8 & & $7.20^{\star \star}$ & 11.60 & $300.00 * \star$ & $216.00^{\star \star}$ \\
\hline 9 & & $6.80^{\star \star}$ & 14.80 & $266.00^{\star \star}$ & $220.00^{* *}$ \\
\hline 10 & & $6.60^{* *}$ & 15.70 & $175.00^{\star}$ & $192.00^{* *}$ \\
\hline 11 & & 5.90 & 16.20 & $300.00 * \star$ & $230.00^{* *}$ \\
\hline 12 & & $6.50^{\star \star}$ & 14.00 & $160.00^{\star}$ & $180.00^{\star *}$ \\
\hline 13 & & $6.80^{\star \star}$ & 15.72 & $278.00^{\star \star}$ & $210.00^{\star \star}$ \\
\hline 14 & & $6.70^{* *}$ & 15.00 & $200.00^{*}$ & $140.00^{* *}$ \\
\hline 15 & & $9.30^{\star \star}$ & 19.20 & $265.00^{\star \star}$ & $300.00^{\star \star}$ \\
\hline 16 & & $7.40^{\star \star}$ & 17.00 & $287.00^{\star \star}$ & $256.00^{\star \star}$ \\
\hline 17 & & $7.60^{\star \star}$ & 17.10 & $280.00^{\star \star}$ & $265.00^{\star \star}$ \\
\hline 18 & & $7.00^{\star \star}$ & 16.00 & $160.00^{*}$ & $152.00^{* *}$ \\
\hline 19 & & $7.60^{\star \star}$ & 16.60 & 249.00 & $215.00^{\star \star}$ \\
\hline 20 & & $7.60^{\star \star}$ & 14.60 & $310.00 \star \star$ & $240.00^{\star *}$ \\
\hline 21 & & $7.80^{* *}$ & 14.00 & $260.00^{\star \star}$ & $210.00^{* *}$ \\
\hline 22 & & $7.20^{\star \star}$ & 14.00 & $275.00^{\star \star}$ & $188.00^{\star \star}$ \\
\hline 23 & \multirow{2}{*}{ Indus River } & $10.20 \star \star$ & 14.00 & $273.37 \star \star$ & $144.00^{\star *}$ \\
\hline 24 & & $10.20^{\star \star}$ & 14.40 & $282.00^{\star \star}$ & $160.00^{\star \star}$ \\
\hline 25 & \multirow{2}{*}{ Spring } & $10.08^{\star *}$ & 15.80 & $288.00^{* *}$ & $160.00^{\star \star}$ \\
\hline 26 & & $9.30^{\star \star}$ & 16.00 & $273.08^{\star \star}$ & $148.00^{\star \star}$ \\
\hline 27 & \multirow{7}{*}{ Tube well } & $7.40^{\star \star}$ & 16.00 & $177.00^{\star}$ & $204.00^{\star \star}$ \\
\hline 28 & & $6.90^{* *}$ & 16.00 & 235.29 & $220.00^{* *}$ \\
\hline 29 & & $8.90^{\star \star}$ & 14.80 & $277.00^{\star \star}$ & $282.00^{\star \star}$ \\
\hline 30 & & $9.60 * \star$ & 15.00 & 269.00 ** & $165.00^{\star \star}$ \\
\hline 31 & & $7.60^{* \star}$ & 16.80 & $302.00^{* *}$ & $160.00^{* *}$ \\
\hline 32 & & $6.60^{* *}$ & 15.20 & $173.07^{\star}$ & $160.00^{\star \star}$ \\
\hline 33 & & $7.80^{\star \star}$ & 15.89 & $179.7^{\star}$ & 162.00 ** \\
\hline
\end{tabular}

* Indicates lower level than the WHO standard.

** Indicates higher level than the WHO standard.

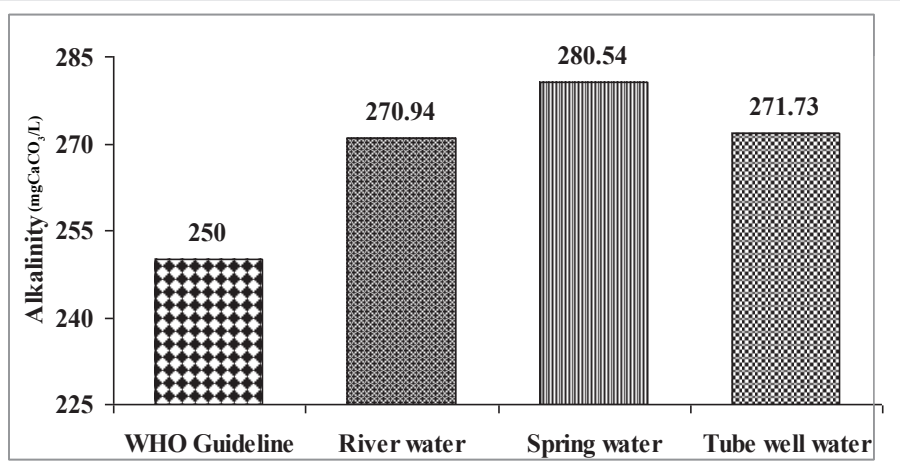

Figure 3: Mean alkalinity concentration of three water sources compared with drinking water quality standard of WHO.

Phosphate $\left(\mathrm{PO}_{4^{3-}}\right)$ may occur in groundwater because of domestic sewage, detergents, agricultural effluents with 


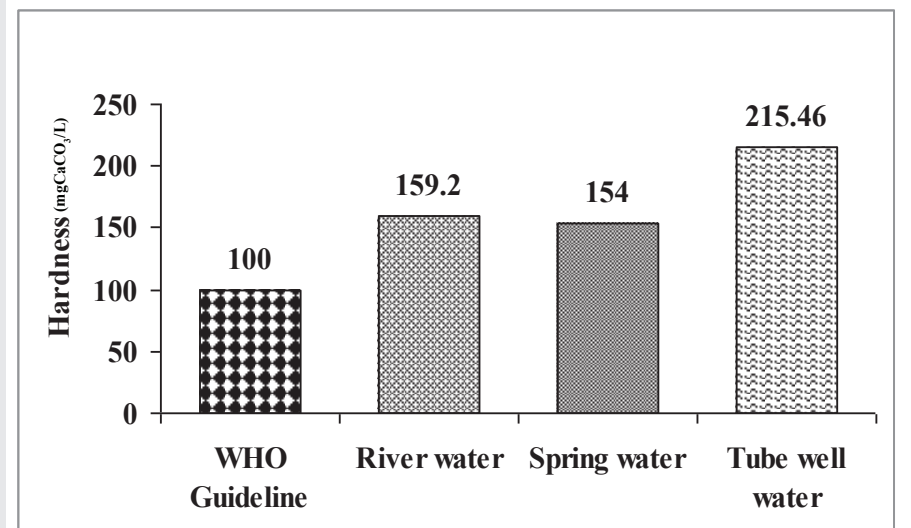

Figure 4: Mean total hardness concentration of three water sources compared with drinking water quality standard of WHO.

Table 5: Different cationic and anionic analytes of water collected from different sites at high altitude.

\begin{tabular}{|c|c|c|c|c|c|}
\hline Sites no. & Water sources & $\begin{array}{c}\text { Chloride } \\
\text { (mg/L) }\end{array}$ & $\begin{array}{c}\mathrm{PO}^{4-} \\
(\mathrm{mg} / \mathrm{L})\end{array}$ & $\mathrm{SO}_{4}^{-}(\mathrm{mg} / \mathrm{L})$ & $\mathrm{NO}_{3}^{-}(\mathrm{mg} / \mathrm{L})$ \\
\hline 1 & \multirow{3}{*}{ Indus river } & $29.99 *$ & ND & $43.71^{\star}$ & $0.138^{\star}$ \\
\hline 2 & & $26.94^{*}$ & ND & $46.31^{*}$ & $0.180^{\star}$ \\
\hline 3 & & $25.29 *$ & ND & $54.34^{\star}$ & $0.002^{\star}$ \\
\hline 4 & \multirow{19}{*}{ Tube well } & $14.54^{*}$ & ND & $38.04^{\star}$ & $0.041^{*}$ \\
\hline 5 & & $12.76^{*}$ & ND & $75.14^{\star}$ & $0.140^{*}$ \\
\hline 6 & & $14.52^{*}$ & ND & $71.83^{\star}$ & $0.097^{*}$ \\
\hline 7 & & $12.87^{\star}$ & ND & $12.71^{\star}$ & $0.583^{\star}$ \\
\hline 8 & & $16.42^{*}$ & ND & $31.19 *$ & $0.708^{*}$ \\
\hline 9 & & $12.53^{*}$ & ND & $41.35^{\star}$ & $0.023^{*}$ \\
\hline 10 & & $13.97^{*}$ & ND & $41.58^{\star}$ & $0.012^{*}$ \\
\hline 11 & & $16.01 *$ & ND & $36.15^{\star}$ & $0.029 *$ \\
\hline 12 & & $16.04^{*}$ & ND & $35.68^{\star}$ & $0.026^{*}$ \\
\hline 13 & & $14.62^{*}$ & ND & $37.80^{\star}$ & $0.004^{\star}$ \\
\hline 14 & & $12.89 *$ & ND & $36.62^{\star}$ & $0.020^{*}$ \\
\hline 15 & & $23.86^{*}$ & ND & $50.33^{\star}$ & $0.357^{*}$ \\
\hline 16 & & $23.42^{\star}$ & ND & $11.53^{\star}$ & $0.099 *$ \\
\hline 17 & & $26.72^{*}$ & ND & $63.32^{\star}$ & $0.036^{*}$ \\
\hline 18 & & $26.50^{*}$ & ND & $52.45^{\star}$ & $0.190 *$ \\
\hline 19 & & $24.43^{*}$ & ND & $32.60 *$ & $0.015^{*}$ \\
\hline 20 & & $25.29 *$ & ND & $44.42^{\star}$ & $0.038^{*}$ \\
\hline 21 & & $27.42^{\star}$ & ND & $83.41^{\star}$ & $0.031^{*}$ \\
\hline 22 & & $22.88^{*}$ & ND & $18.66^{\star}$ & $0.176^{\star}$ \\
\hline 23 & \multirow{2}{*}{ Indus river } & $16.06^{*}$ & ND & $71.83^{\star}$ & $0.027^{*}$ \\
\hline 24 & & $26.04^{\star}$ & ND & $72.30^{\star}$ & $0.065^{\star}$ \\
\hline 25 & \multirow{2}{*}{ Spring Water } & $15.80^{*}$ & ND & $8.99 *$ & $4.411^{*}$ \\
\hline 26 & & $16.92^{*}$ & ND & $37.09 *$ & $0.023^{*}$ \\
\hline 27 & \multirow{7}{*}{ Tube well } & $24.86^{*}$ & ND & $36.62^{\star}$ & $0.087^{*}$ \\
\hline 28 & & $22.76^{*}$ & ND & $20.32^{\star}$ & $0.008^{*}$ \\
\hline 29 & & $22.65^{*}$ & ND & $13.30^{*}$ & $1.480 *$ \\
\hline 30 & & $24.52^{\star}$ & ND & $10.66^{\star}$ & $0.005^{\star}$ \\
\hline 31 & & $20.89 *$ & ND & $12.99 *$ & $1.260^{\star}$ \\
\hline 32 & & $27.64^{*}$ & ND & $25.52^{\star}$ & $0.560^{*}$ \\
\hline 33 & & $27.98^{\star}$ & ND & $38.04^{\star}$ & $0.041^{*}$ \\
\hline
\end{tabular}

fertilizers and industrial waste water [11]. The phosphate content in most of the study area was not detectable (Table 5). Since, all the samples were collected in the winter season. During winter season, domestic sewage is very low and no agriculture activity. Moreover, not much industry has been established, hence phosphate contaminants was under detectable limit.

Sulphate $\left(\mathrm{SO}_{4}{ }^{2-}\right)$ occurs naturally in water because of leaching from gypsum and other common minerals [36]. Low levels of sulphate (Table 5, Figure 6) in the study area were indicating low level of leaching from the igneous, metamorphic and sedimentary rocks of this region.

Nitrate $\left(\mathrm{NO}_{3}^{-}\right)$being the highly oxidized form of nitrogen compounds, which is present in the surface and groundwater sources [37]. Significant sources of nitrates are fertilizers, decayed vegetable and animal matter, domestic and industrial effluents and atmospheric washouts. In our study, nitrate concentration (Table 5, Figure 7) was below the permissible limit in all sources of water. Therefore, it might be said that drinking water might be free from hazardous sources as mainly the zero levels agricultural system.

Sodium (Na) concentration plays an important role in evaluating the groundwater quality for irrigation because sodium causes an increase in the hardness of soil as well as a reduction in its permeability [38]. For the low level of sodium concentration (Figure 8 ) in the study area, cultivation might be affected with low production.

The major source of potassium (K) in natural fresh water is weathering of rocks but the quantities increase in the polluted water due to disposal of waste water [25]. Average potassium level was higher in the nearby city area. Therefore, it can be said that, disposal of waste water in water sources nearby city area is more than the other area. Ruminants are largely depends on non-protein nitrogen sources, such as urea, biuret, or ammonium phosphate. Inadequate level of sulfur in the study area might be effect on the feed intake, digestibility, rate of weight gain, and milk production [39]. Manganese $(\mathrm{Mn})$ is often associated with calcium in all kinds of waters, but its concentration remains generally lower than the calcium [40]. In this study, low levels of Mn can potentially lead to a decrease in overall animal growth [41]. In most of the analyzed water samples, iron and aluminium were above the permissible limit. Most of the groundwater samples contain iron and aluminum in trace amounts in practically all sediments and rock formations [25,42]. So, it may have adverse effect on long-term consumption of these water $[43,44]$. Hence, these findings indicated contamination of some water sources at certain sites, which seem to be investigated in time-to-time for devising some remedial measures. As this is a first time report on these parameters and different water sources at high altitude, however further studies are required to analyze more samples collected across the location in different seasons for comprehensive understanding of these variations in physicochemical and mineral parameters (Table 6, Figure 9-13).

Overall quality of the drinking water has shown higher level 
of alkalinity, hardness, potassium, iron, and aluminium level. High alkalinity and hardness of water may be corrected boiling followed by the filtration. However, gravity or reverse osmosis (RO) based multi staged filter would be useful for removal of

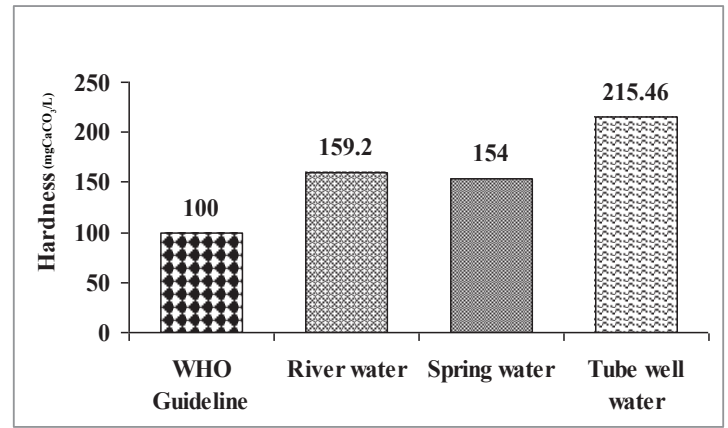

Figure 5: Mean chloride concentration of three water sources compared with drinking water quality standard of WHO.

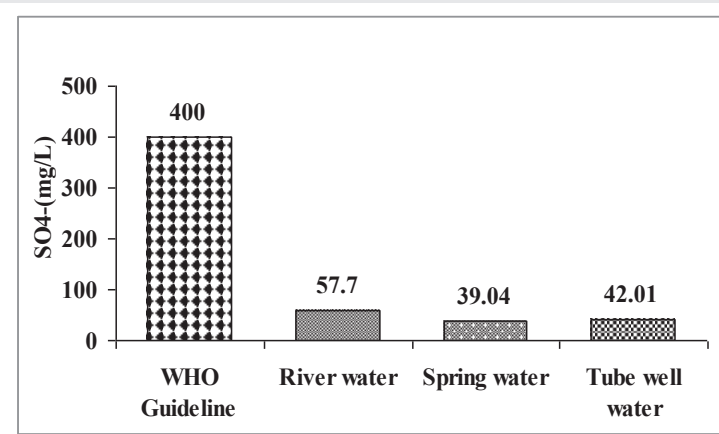

Figure 6: Mean sulphate concentration of three water sources compared with drinking water quality standard of WHO.

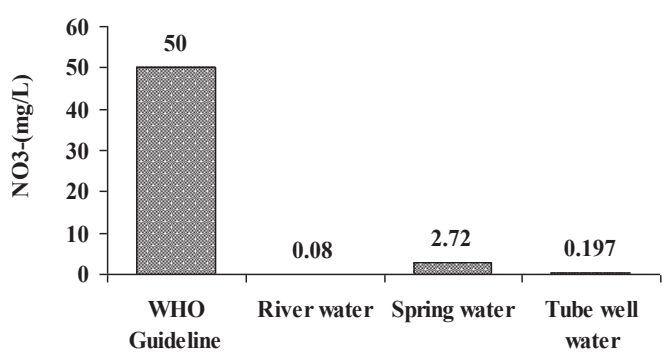

Figure 7: Mean nitrate concentration of three water sources compared with drinking water quality standard of WHO.

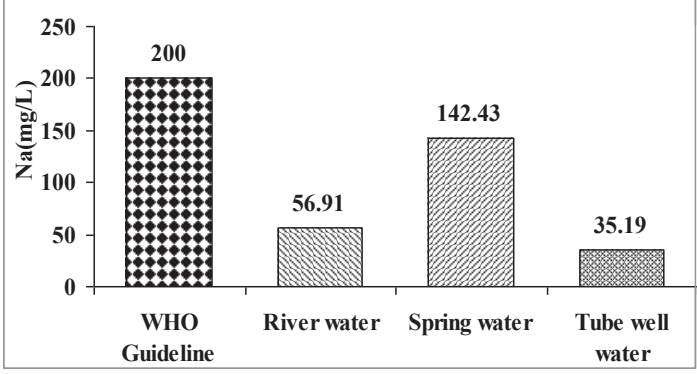

Figure 8: Mean sodium concentration of three water sources compared with drinking water quality standard of WHO.

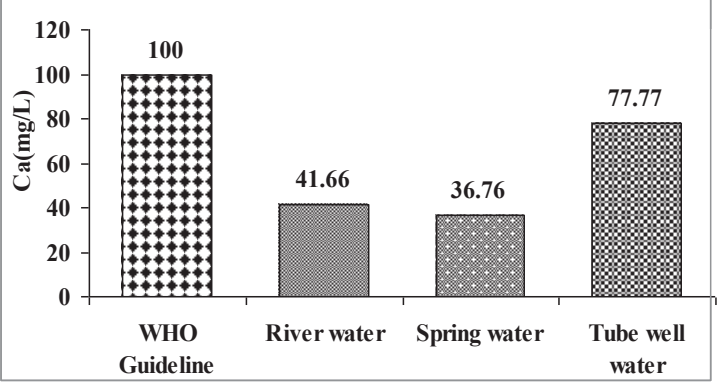

Figure 9: Mean calcium concentration of three water sources compared with drinking water quality standard of WHO.

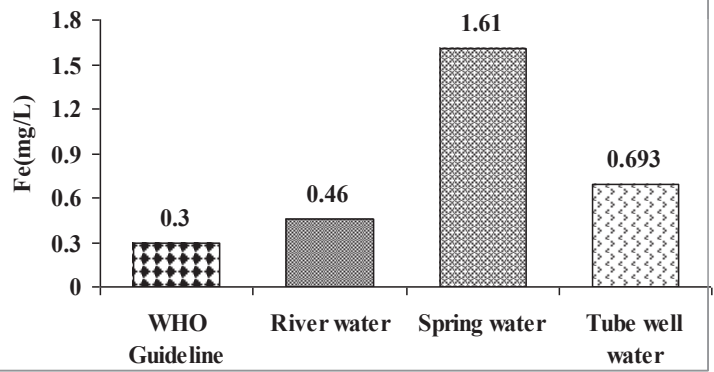

Figure 10: Mean iron concentration of three water sources compared with drinking water quality standard of WHO.

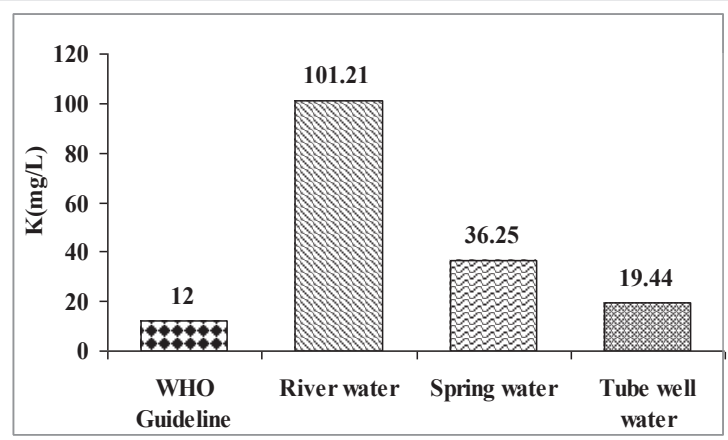

Figure 11: Mean potassium concentration of three water sources compared with drinking water quality standard of WHO.

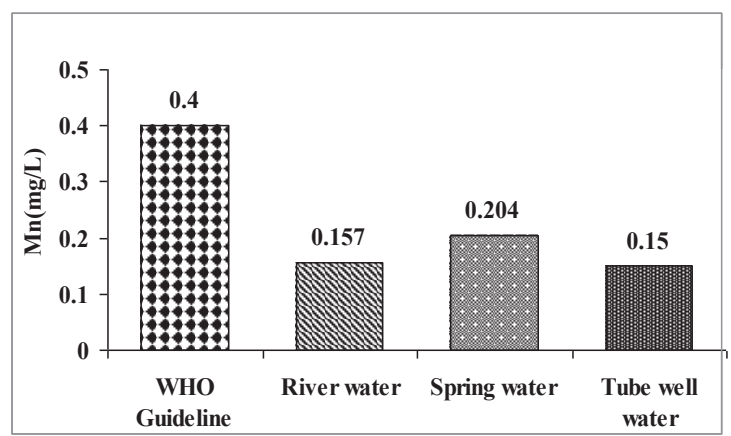

Figure 12: Mean manganese concentration of three water sources compared with drinking water quality standard of WHO.

excess inorganic salts and minerals. Since, the high altitude region has limited electricity coverage, so RO filter may not be feasible and gravity based filter has limited capacity to remove 
Table 6: Minerals analytes of water collected from different sites at high altitude.

\begin{tabular}{|c|c|c|c|c|c|c|c|c|c|}
\hline Sites no. & Water sources & $\begin{array}{c}\mathrm{Mg} \\
(\mathrm{mg} / \mathrm{L})\end{array}$ & $\begin{array}{c}\mathrm{Fe} \\
(\mathrm{mg} / \mathrm{L})\end{array}$ & $\begin{array}{c}\mathrm{Na} \\
(\mathrm{mg} / \mathrm{L})\end{array}$ & $\begin{array}{c}\mathrm{K} \\
(\mathrm{mg} / \mathrm{L})\end{array}$ & $\begin{array}{c}\mathrm{S} \\
(\mathrm{mg} / \mathrm{L})\end{array}$ & $\begin{array}{c}\mathrm{Mn} \\
(\mathrm{mg} / \mathrm{L})\end{array}$ & $\begin{array}{c}\mathrm{Al} \\
(\mathrm{mg} / \mathrm{L})\end{array}$ & $\begin{array}{c}\mathrm{Ca} \\
(\mathrm{mg} / \mathrm{L})\end{array}$ \\
\hline 1 & \multirow{3}{*}{ Indus river } & $6.05^{\star}$ & 0.302 & $47.12^{\star}$ & $0.30^{*}$ & 85.81 & $0.147^{*}$ & 0.347 & $38.30 *$ \\
\hline 2 & & $5.28^{*}$ & $0.276^{\star}$ & $79.53^{*}$ & $94.80^{\star \star}$ & 92.57 & $0.147^{\star}$ & 0.303 & $40.02^{*}$ \\
\hline 3 & & $6.20^{\star}$ & 0.304 & $58.71^{*}$ & $100.10^{\star *}$ & 71.59 & $0.165^{\star}$ & $1.874^{\star *}$ & $45.90^{*}$ \\
\hline 4 & \multirow{19}{*}{ Tube well } & $12.20 *$ & $0.786^{\star \star}$ & $24.31^{*}$ & $8.03^{\star}$ & 30.27 & $0.146^{\star}$ & $2.838^{\star \star}$ & $70.96^{*}$ \\
\hline 5 & & $11.89 *$ & $0.876^{* *}$ & $45.41^{*}$ & $8.61^{*}$ & 41.75 & $0.145^{\star}$ & $2.115^{\star \star}$ & $71.36^{*}$ \\
\hline 6 & & $16.35^{\star}$ & $0.197^{\star}$ & $30.68^{*}$ & $3.11^{*}$ & 43.74 & $0.162^{*}$ & $1.302^{\star \star}$ & $92.71 *$ \\
\hline 7 & & $16.37^{*}$ & $0.695^{\star \star}$ & $25.90^{*}$ & $6.05^{*}$ & 77.91 & $0.195^{\star}$ & $2.756^{\star \star}$ & $117.00^{* \star}$ \\
\hline 8 & & $14.35^{*}$ & $0.414^{\star \star}$ & $25.33^{*}$ & $3.90^{*}$ & 38.20 & $0.141^{*}$ & $0.887^{\star *}$ & $68.75^{\star}$ \\
\hline 9 & & $11.81^{*}$ & $1.329 * \star$ & $22.28^{\star}$ & $6.92^{*}$ & 67.45 & $0.153^{*}$ & $4.100^{* *}$ & $69.88^{*}$ \\
\hline 10 & & $11.39 *$ & $1.420 * \star$ & $20.12^{*}$ & 66.50 ** & 50.99 & $0.150^{\star}$ & $1.085^{\star \star}$ & $66.97^{*}$ \\
\hline 11 & & $13.70^{*}$ & $0.453^{\star \star}$ & $29.99^{*}$ & $7.05^{\star}$ & 65.57 & $0.145^{\star}$ & $0.980^{* *}$ & $77.53^{*}$ \\
\hline 12 & & $11.00 *$ & $2.307^{\star \star}$ & $22.25^{\star}$ & $3.03^{*}$ & 46.16 & $0.153^{*}$ & $0.907^{\star *}$ & $56.09 *$ \\
\hline 13 & & $11.80^{*}$ & $1.151^{\text {** }}$ & $21.21^{*}$ & $7.51^{*}$ & 51.12 & $0.146^{*}$ & $1.083^{\star *}$ & $73.52^{\star}$ \\
\hline 14 & & $4.15^{\star}$ & $2.054^{\star \star}$ & $8.85^{\star}$ & $1.01 *$ & 11.69 & $0.156^{\star}$ & $1.134^{\star \star}$ & $55.62^{\star}$ \\
\hline 15 & & $14.11^{*}$ & $0.079^{*}$ & $24.10^{*}$ & $97.71^{\star \star}$ & 88.88 & $0.138^{*}$ & $0.055^{\star}$ & 77.50 * \\
\hline 16 & & $10.41^{*}$ & $1.041^{\star \star}$ & $26.34^{\star}$ & $10.17^{\star}$ & 56.85 & $0.919^{*}$ & $2.077^{\star \star}$ & $69.02^{*}$ \\
\hline 17 & & $13.28^{*}$ & $0.588^{* \star}$ & $36.67^{*}$ & $7.89 *$ & 72.90 & $0.139 *$ & $2.652^{\star \star}$ & $83.24^{*}$ \\
\hline 18 & & $3.48^{\star}$ & $0.728^{\star \star}$ & $6.67^{*}$ & $1.30 *$ & 18.33 & $0.145^{*}$ & $2.184^{\star \star}$ & $56.51^{*}$ \\
\hline 19 & & $11.82^{*}$ & $3.463^{\star \star}$ & $28.23^{\star}$ & $6.12^{\star}$ & 47.14 & $0.165^{\star}$ & $1.256^{* *}$ & $81.60 *$ \\
\hline 20 & & $15.19 *$ & $1.003^{\star \star}$ & $26.32^{\star}$ & $33.62^{\star *}$ & 86.43 & $0.155^{\star}$ & $1.251^{\text {** }}$ & 107.40 \\
\hline 21 & & $12.97^{*}$ & $0.975^{\star \star}$ & 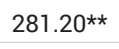 & $26.82^{\star \star}$ & 107.40 & $0.259^{\star}$ & $2.535^{\star \star}$ & $126.90^{* \star}$ \\
\hline 22 & & $5.40^{\star}$ & 0.450 ** & $6.53^{*}$ & $1.29 *$ & 14.02 & $0.142^{*}$ & $2.506^{\star \star}$ & $71.43^{*}$ \\
\hline 23 & \multirow{2}{*}{ Indus river } & $5.05^{\star}$ & $1.372^{\star \star}$ & $10.81^{*}$ & $3.52^{\star}$ & 27.20 & $0.177^{*}$ & $1.687^{* \star}$ & $52.99 *$ \\
\hline 24 & & $6.32^{\star}$ & $0.860^{\star *}$ & $55.35^{*}$ & $114.30^{\star *}$ & 35.18 & $0.146^{*}$ & $0.002^{*}$ & $31.09 *$ \\
\hline 25 & \multirow{2}{*}{ Spring Water } & $3.45^{\star}$ & $0.540^{\star \star}$ & $6.90^{\star}$ & $40.05^{\star \star}$ & 35.06 & $0.136^{\star}$ & $0.033^{*}$ & $31.05^{*}$ \\
\hline 26 & & $4.68^{\star}$ & $3.162^{\star \star}$ & $7.96^{\star}$ & $2.45^{\star}$ & 14.47 & $0.273^{*}$ & $2.535^{\star \star}$ & $42.48^{*}$ \\
\hline 27 & \multirow{7}{*}{ Tube well } & $4.91^{*}$ & 0.739 ** & $5.66^{*}$ & $1.36^{\star}$ & 19.95 & $0.147^{\star}$ & $2.607^{\star \star}$ & $72.45^{*}$ \\
\hline 28 & & $5.53^{\star}$ & $0.657^{\star \star}$ & $4.87^{\star}$ & $1.61^{\star}$ & 15.99 & $0.146^{\star}$ & $1.662^{\star \star}$ & $71.98^{*}$ \\
\hline 29 & & $6.70^{\star}$ & $0.070^{\star}$ & $22.72^{\star}$ & $48.77^{\star \star}$ & 113.10 & $0.166^{\star}$ & $0.050^{*}$ & $73.39 *$ \\
\hline 30 & & $7.43^{\star}$ & $2.433^{\star \star}$ & $34.37^{\star}$ & 15.30 ** & 279.00 & $0.238^{*}$ & $1.280^{* *}$ & 105.20 \\
\hline 31 & & $5.56^{\star}$ & $0.063^{*}$ & $24.39 *$ & 58.24 * & 109.00 & $0.161^{*}$ & $0.022^{*}$ & $56.96^{*}$ \\
\hline 32 & & $5.83^{\star}$ & $0.069 *$ & $36.38^{\star}$ & $83.45^{\star \star}$ & 59.16 & $0.145^{\star}$ & $0.016^{\star}$ & $47.03^{\star}$ \\
\hline 33 & & $5.20^{\star}$ & $0.786^{\star \star}$ & $24.31^{*}$ & $8.03^{\star}$ & 30.27 & $0.146^{\star}$ & $2.838^{* *}$ & $70.96^{*}$ \\
\hline
\end{tabular}

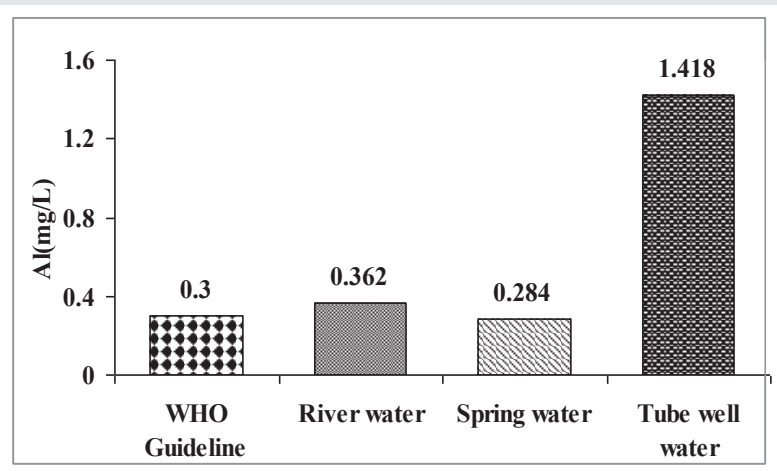

Figure 13: Mean aluminium concentration of three water sources compared with drinking water quality standard of WHO.

the soluble metal salt contaminants. Hence, research should be undertaken to develop economic and user friendly individual or community based water treatment system using activated charcoal, nanoadsorbant, metal chelators, etc.

\section{Conclusions}

The present investigation findings indicated variations in physico-chemical parameters and mineral status of water of different sources. Further, there was wide variation of water quality constituents among different sources of water. Physical parameters like alkalinity and hardness were higher than WHO standard level at different altitude. Among minerals, iron, potassium and aluminium level were more than the prescribed ground water quality limits by WHO. Interestingly, chloride, sodium, sulphur and aluminium level were high in Indus river water collected from the nearby city area. Therefore, it can be concluded that water sources near the city area are contaminated. However, more or less, the quality of drinking 
water is suitable for consumption except the hardness and aluminium level. Though, this study finding further advocates the extensive study on water quality of different sources at high altitude.

\section{Acknowledgements}

The Authors are thankful to Director, DIHAR and Defence Research and Developmental Organization (DRDO), New Delhi, India, for financial support. We are also thankful to technical staffs and SRF Prabhat Kumar for their help throughout the sampling period and technical assistance, Sahil Kapoor, SRF for drawing map.

\section{References}

1. National Academy of Sciences (1977) Drinking water and health, National Academy Press, Washington, DC. 1.

2. World Health Organization (1996) International Program of Chemical Safety. Guidelines for drinking-water quality, Health criteria and other supporting information. 2nd Edn, Geneva. Link: https://goo.gl/CBEwm3

3. Prakash KL, Somashekar R K (2006) Ground water quality assessment on Anekal Taluk, Bangalore Urban district, India. J Environ Biol 27: 633-637. Link: https://goo.gl/kYpKOl

4. IWRA (2000) Water Resources Management into the 21 st Century: Focus Session of the Xth World Water Congress of IWRA. Water Inter 25: 2

5. Gupta DP, Sunita, Saharan JP (2009) Physiochemical Analysis of Ground Water of Selected Area of Kaithal City (Haryana) India. Researcher 1: 1-5. Link: https://goo.gl/lt5jRq

6. Kumar N (1997) A View on Freshwater environment. Indian J Environ Ecoplan 3: 3-4.

7. Moore PD, Daniel TC, Gilmour JT, Shereve BR, Edward DR, et al. (1998) Decreasing Metal Runoff from Poultry Litter with Aluminium Sulfate. J Environ Quali 27: 92-99. Link: https://goo.gl/IZjsGe

8. Badmus, Leachate BS (2001) Contamination effect on ground water exploration. Afri J Environ Studies 2: 38-41

9. Iqbal MA, Gupta SG (2009) Studies on Heavy Metal Ion Pollution of Ground Water sources as an Effect of Municipal Solid Waste Dumping. Afri J Basic Applied Sci, 1: 117-122. Link: https://goo.gl/neCDn8

10. Szefer P, Nriagu JO (2007) Mineral components in Foods, CRC press, USA. 123. Link: https://goo.gl/XRjf6k

11. Taha AA, El-Mahmoudi AS, El-Haddad IM (2004) Pollution Sources and Related Environmental Impacts in the New Communities' Southeast Nile Delta, Egypt. Emirates J Eng Res 9: 35-49. Link: https://goo.gl/SotjlH

12. Aregheore EM, Hunter D, Perera D, Mautoatasi MT (2007) The soil-plantanimal phenomena: Serum mineral status of Fuji fantasticsheepgrazing Batiki grass (Ischaemum aristatumVar. indicum) and Pangola grass (Digitaria decumbens) in Samoa. J Anim Vet Advan 6: 349-357. Link: https://goo.gl/YNCFu8

13. Gonul R, Kayar A, Bilal T, Erman ORM, Parkan DVM, et al. (2009) Comparison of mineral levels in bone and blood serum of cattle in Northwestern Turkey. J Anim Vet Advan 8: 1263-1267. Link: https://goo.gl/YNCFu8

14. Kincaid RI (1999) Assessment of trace mineral status of ruminants: A review. Proceed American Soci Anim Sci 77: 1-10. Link: https://goo.gl/rFAeAb

15. Bruvold WH, Ongerth HJ (1969) Taste Quality of Mineralized Water. J American Water Works Asso 61: 170-174. Link: https://goo.gl/RU0pfn
16. Mishra PC, Patel RK (2001) Study of the pollution load in the drinking water of Rairangpur, a small tribal dominated town of North Orissa. Indian J Environ Ecoplan 5: 293 -298. Link: https://goo.gl/T4KoLX

17. Charan G, Bharti VK, Jadhav SE, Kumar S, Angchok D, et al. (2013) Altitudinal variations in soil physico-chemical properties at cold desert high altitude. $\mathrm{J}$ Soil Sci Plant Nutri 7: 6313-6319. Link: https://goo.gl/T4KoLX

18. Charan G (2013) Studies on certain essential minerals status and heavy metals presents in soil, plant, water and animal at high altitude cold arid environment, Ph.D. Thesis, JAYPEE University of Information Technology, waknaghat, Solan, India. Link: https://goo.gl/v7xkQ5

19. Reza R, Singh G (2009) Physico-Chemical Analysis of Ground Water in AngulTalcher Region of Orissa. J Anim Sci 5: 53-58. Link: https://goo.gl/0BfmG6

20. Muller BA (2001) Residential Water Source and the Risk of Childhood Brain Tumors. Environ Health Perspective 109: 551-556. Link: https://goo.gl/qeuAj0

21. District Ground Water Information Brochure, Leh district, (2011) Ground water information brochure of Leh district Jammu and Kashmir State. 1-15. Link: https://goo.gl/qeuAj0

22. Singh D, Chhonkar PK, Dwivedi BS (2005) Manual on Soil, Plant and Water Analysis. Westville Publishing House, New Delhi, 200. Link: https://goo.gl/rWwnkU

23. Manivaskam A (1997) Analysis of water and wastewater. Pragathi Prakasan Publications.

24. APHA and AWWA (1985) Standard Methods for the examination of water \& waste water. 18th Edn., Washington, DC. Link: https://goo.gl/Q9YZb5

25. Trivedy RK, Goel PK (1986) Chemical and Biological methods for wate pollution studies. Environ Publi 248. Link: https://goo.gl/VggTLx

26. World Health Organization (2003) Guidelines for Drinking Water Quality, Health Criteria and Other Supporting Information, 2nd Edn, 2. Link: https://goo.gl/dyQWRQ

27. Gorde SP, Jadhav MV (2013) Assessment of Water Quality Parameters: A Review. Int. J Eng Res Appl 3: 2029-2035.

28. Deshmukh JU, Ambore NE (2006) Seasonal variations in physical aspects of pollution in Godavari River at Nanded, Maharashtra, India. J Aqua Biol 21 93-96

29. Vijayan VS (1991) Keoladeo National Park Ecology Study, Final report (19801990), BNHS, Bombay.

30. Reddy VK, Laxmi PK, Swamy M, Reddy RT (2009) Physico-chemical parameters of Pakhal lake of Warangal district, Andhra Pradesh, India. $J$ Aqua Biol 24: 77-80.

31. William A, Wurts Durborow RM (1992) Interactions of pH, Carbon Dioxide Alkalinity and Hardness in Fish Ponds, Southern Regional Aquaculture Center, 46: 1-4. Link: https://goo.gl/r48IDM

32. Kinniburgh DG, Edmunds WM (1986) The Susceptibility of UK Ground-waters to Acid Deposition, Hydro geological Report 86/3, British Geological Survey, Wallingford, UK. 208.

33. Sirsath DB, Ambore NE, Pulle JS, Thorat DH (2006) Studies on the concentration of ion in freshwater pond at Dharampuri, Dist. Beed, India Pollu Res 25: 507-509. Link: https://goo.gl/blMTTg

34. Freeda DGR, Arunkumar K, Valarmathy (2006) Portability of drinking water sources of Eleven Villages in Perambalur District, Tamil Nadu. Pollu Res 25 171-174.

Citation: Bharti VK, Giri A, Kumar K (2017) Evaluation of Physico-Chemical Parameters and Minerals Status of Different Water Sources at High Altitude. Ann Environ Sci Toxicol 2(1): 010-018. DOI: https://dx.doi.org/10.17352/aest.000007 
35. Hughes JL (2004) Evaluation of groundwater Degradation Result from Waste Disposal to Alluvium near Barstow, California, US, Geological survey professional Paper, 878. Link: https://goo.gl/sA4eix

36. Mekee JE, Wolf HW (1981) Water Quality Criteria, The Resource Agency of California State Water Quality Control board. Link: https://goo.gl/RM9Uvs

37. Puckett LJ, Cowdery TK (2002) Transport and Fate of Nitrate in a Glacial Outwash Aquifer in Relation to Ground Water Age, Land Use Practices, and Redox Processes, J Environ Qul 31: 782-796. Link: https://goo.gl/TzBKwE

38. Tijani MN (1994) Hydrochemical assessment of ground-water in Moro area Kwara State. Nigerian Environ Geol 24: 194-202. Link: https://goo.gl/Ynjkz1

39. Hays VW, Swenson MJ (1985) Minerals and bones. In: Dukes' Physiology of Domestic Animals. 10th Edn, Cornell University Press, London, UK. 449-466.

40. Venkatasubramani R, Meenambal T (2007) Study of subsurface water quality in Mattupalayam Taluk of Coimbatore district Tamil Nadu. Nature Environ Pollu Technol 6: 307-310. Link: https://goo.gl/MvrkoF

41. Prasad AS (1984) Trace Metals in Growth and Sexual Maturation. Metabolism of Trace Metals in Man. Developmental Aspect, CRC Press Inc., Florida. 1: 7997

42. Bakare-Odunola MT (2005) Determination of some metallic impurities present in soft drinks marketed in Nigeria. Nigerian J Pharmacol 4: 51-54.

43. Bothwell TH, Charlton RW, Cook JD, Finch CA (1979) Iron Metabolism in Man Blackweel Scientific, Oxford. Link: https://goo.gl/58qMpW

44. Taiwo AA, Idowu O, Lanre-Lyanda YA, Jolaoso AA, Jiboku OO, et al (2012) Physicochemical and bacteriological analyses of sachet water samples in Abeokuta metropolis. Glob Adv Res J Agri Sci 1: 1-6. Link: https://goo.gl/PH8jEL

Copyright: () 2017 Bharti VK, et al. This is an open-access article distributed under the terms of the Creative Commons Attribution License, which permits unrestricted use, distribution, and r eproduction in any medium, provided the original author and source are credited. 